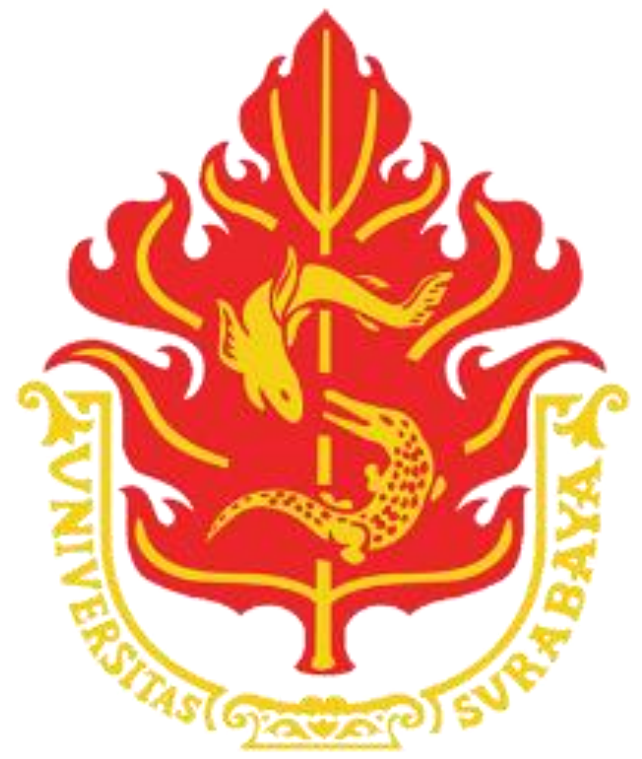

KP A

CHRISTIN FELLICIA ISMANTO

130218007

FAKULTAS BISNIS DAN EKONOMIKA

UNIVERSITAS SURABAYA

Genap 2020/2021 


\title{
IMPLEMENTATION THE SUPPLY CHAIN OF FRUIT AND VEGETABLES IN EAST JAVA, INDONESIA
}

\author{
1Ahmad Zafrullah Tayibnapis, 2Lucia Endang Wuryaningsih
}

1Lecturer of Business and Economic Faculty of Surabaya University, Surabaya, Indonesia 2Lecturer

of Pharmacy Faculty of Surabaya University, Surabaya, Indonesia

\section{Review}

Developments in the fruit and vegetable sector play an important role in Indonesia's economic growth, one of which is in the East Java region. With this development it helps create jobs. East Java has great potential and is a major supplier of food crops, animal and horticultural needs compared to other regions in Indonesia. Therefore East Java has a higher comparative advantage because the area of East Java has adaptive climatic, soil, and topophographical conditions. For example, in Malang, Pacet, Pasuruan, Probolinggo, Kediri, and Lumajang, which have areas suitable for the development of fruits and vegetables. Supply Chain is a further integration of logistics management between the companies involved which has the aim of increasing the flow of goods, increasing the accuracy of demand forecasts, increasing the efficiency of the use of space, vehicles and other facilities, reducing inventory levels, reducing costs, and improving other services. Supply Chain also involves an ongoing relationship regarding existing goods, money and information. Horizontally there are 5 components or main actors in the Supply Chain, namely suppliers, manufacturers, distributors, retailers, and customers. Apart from horizontally, as for vertically, namely the maker, buyer,carrier, storage and seller.

This research aims to analyze the condition of the fruit and vegetable value chain in East Java. This research is focused on the condition of natural objects where the researcher is the key instrument. This research collected data by means of interviews and observations to produce an in-depth and comprehensive analysis. Furthermore, it is hoped that the SWOT analysis and the basic value chain of fruits and vegetables can produce strategies for farmers to obtain margins.

To determine the location of these commodities, it is necessary to determine the altitude which is divided into 3, namely the highlands, medium plains and lowlands. Each land has different types of plants. In the highlands there are vegetables such as potatoes, garlic and cabbage which are widely grown in Pasuruan, Probolinggo, Malang and Magetan. Whereas in the lowlands there are certain types of vegetables, namely chilies, shallots, tomatoes and certain types of garlic. Apart from vegetables, fruit also has a different commodity zone. For mangoes in the north, oranges in the south, and bananas in the south. For mangoes, it is located in northern areas such as Tuban, Lamongan, Gresik, Pasuruan, Probolinggo, Situbondo, and Madura. For Oranges are in Madiun and Magetan. As for Bananas, they are in Mojokerto, Banyuwangi, Malang, and Jombang. 


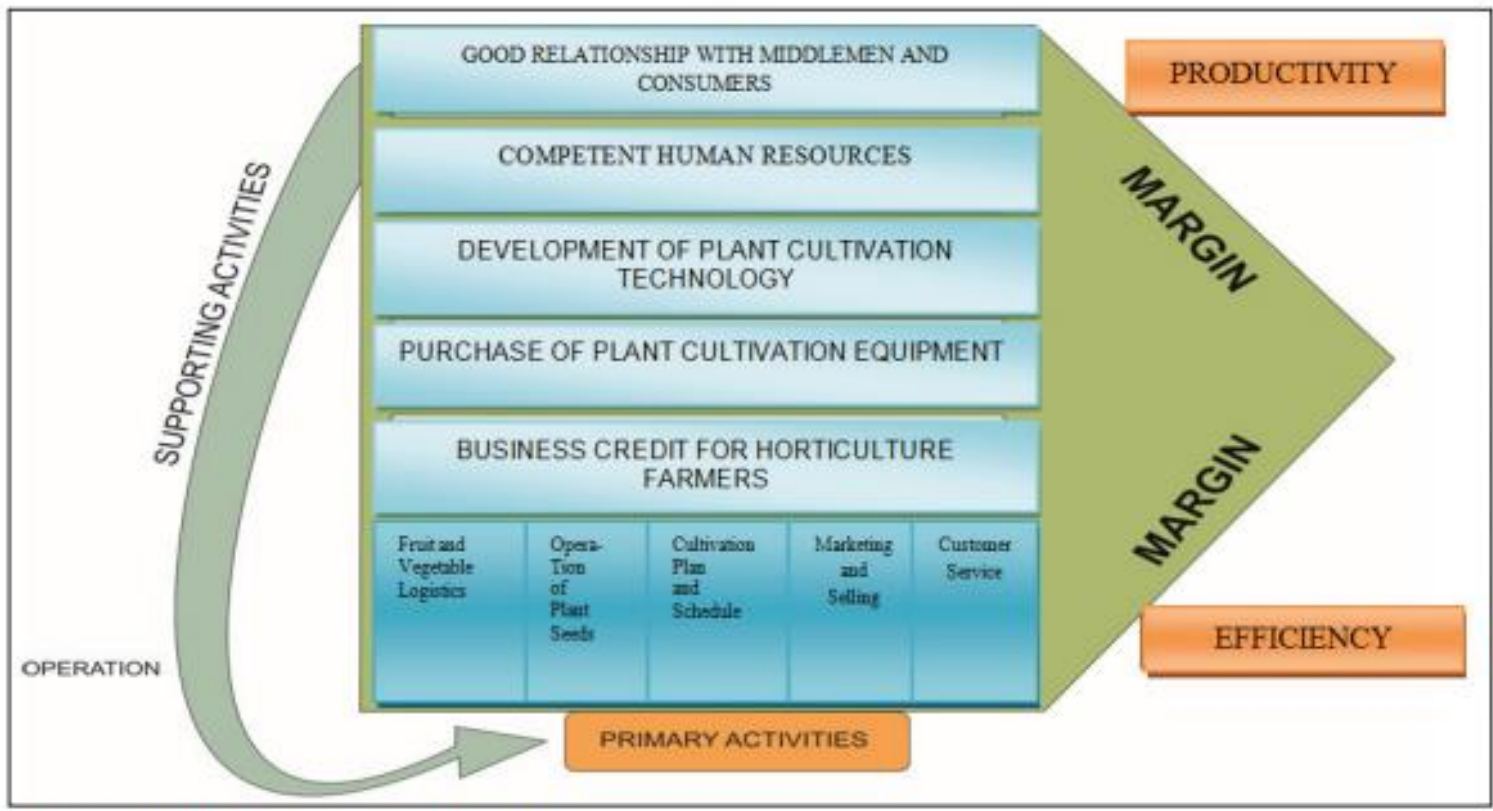

Fig. 3: Basic Value Chain of Fruits and Vegetables Source: [5.7], Researchers, 2016

Regional potential factors and agro-climate suitability for main commodities need to be developed in order to meet domestic and export market demands such as industrial raw materials. Furthermore, the development of superior commodities must be based on the suitability between land resources and production needs of superior commodities and taking into account economic value, market demand, competitive advantage values, marketing facilities, socio-economic conditions of farmers and spatial layout of production areas in the form of commodity production centers in the region. developed into agribusiness.

For the Supply Chain of fruits and vegetables in East Java, it can be changed if both the central and regional governments are serious about increasing production and improving quality. Local governments need to inform and distribute superior seeds with export quality. Fruit and vegetable farmers really need a guarantee of the availability of superior seeds, considering that the seeds that have been distributed by the government to farmers are not good quality seeds. To improve the quality of fruit and vegetable products, of course, farmers need the best quality seeds. But not only seeds are needed, farmers also need technology that is environmentally friendly, affordable, effective and efficient. In addition, farmers need to learn related to the weather in order to reduce the impact of losses due to crop failure during the rainy season.

\section{Conclusion}

The development of fruit and vegetables has a large and positive prospect that is useful for improving nutritional quality, promoting non-oil and gas commodities, and preserving the beauty and sustainability of the environment. For the development of vegetable crops, most of them are still financed by the farmers themselves, especially in areas that are production centers. Upland vegetable crops such as potatoes, cabbage, carrots and garlic are widely grown in Pasuruan, Probolinggo, Malang and Magetan. Certain types of chilies, shallots, tomatoes and garlic are developed in the lowlands which are almost spread throughout East Java, while 
other commodities are developed locally in the low and mediumlands to meet the needs of vegetable diversification.

To increase income, farmers must think about how to sell fruit and vegetables abroad, given that Indonesia is one of the 20 countries in the world that dominate fruit production. In addition, Indonesia has native fruits such as pineapple, mangosteen, avocado and banana. Apart from that, the distribution of fruits and vegetables must be made easier so that the products can arrive at their destination in fresh conditions and can be supplied all year round and not focus on certain seasons.

\section{Reference}

Tayibnapis, Ahmad Zafrullah and Wuryaningsih, Lucia Endang (2019) Evamping the Supply Chain of Fruit and Vegetable in East Java Province, Indonesia 